\title{
Green microfinance: the case of the Cresol System in Southern Brazil
}

\author{
Lauro Gonzalez \\ Fundação Getulio Vargas (FGV-SP) / Centro de Estudos de Microfinanças e Inclusão Financeira \\ São Paulo / SP - Brasil \\ Rafael Magnus Barbosa Moser \\ University of Trento \\ Italy
}

\begin{abstract}
Climate change which until recently seemed a luxury for the microfinance sector, now appears to be crucial for the future of the sector. Due to their low adaptive capacity, the millions of MF clients worldwide happen to be the most vulnerable to a changing climate. Adapting previous analysis conducted in Nepal and Bangladesh by Agrawala and Maëlis (2010) to the Brazilian context, in this inductive qualitative study we aim to assess potential synergies between MF and CC actions and what strategies can be harnessed to better respond to CC vulnerabilities at client/MF level. To do so, we investigated the case of the second largest rural microcredit programme in Brazil, Sistema Cresol de Cooperativas de Crédito Rural com Interação Solidária. Albeit important overlaps between Cresol's product envelope and CC strategies exist, there is still room to realise synergies to both mitigate a new potential source of risk to Cresol's portfolio and to increase clients' adaptive capacity.
\end{abstract}

Keywords: green microfinance; climate change; rural public policies; Pronaf; Cresol.

\section{Microfinanças verdes: o caso do Sistema Cresol na região Sul do Brasil}

As temáticas das mudanças climáticas, que até recentemente pareciam supérfluas para o setor de microfinanças, agora parecem ser cruciais para o futuro do setor. Pela baixa capacidade adaptativa, os milhões de clientes microfinanceiros (MF) mundo afora serão os mais vulneráveis à mudança do clima. Adaptando uma prévia análise de Agrawala e Maelis (2010) no Nepal e em Bangladesh para o contexto brasileiro, este estudo qualitativo indutivo avalia potenciais sinergias entre MF e temáticas de microcrédito $(\mathrm{MC})$, bem como estratégias que podem ser aprimoradas para reduzir vulnerabilidades à MC no nível micro/institucional. Para tanto, investigamos o segundo maior programa de microcrédito rural no Brasil, o Sistema Cresol de Cooperativas de Crédito Rural com Interação Solidária. Embora

DOI: http://dx.doi.org/10.1590/0034-7612134039

(cc) BY-NC

Article submitted on 25 Apr. 2014 and accepted for publication on 27 Jan. 2015.

Rev. Adm. Pública - Rio de Janeiro 49(4): 1039-1058, jul./ago. 2015 
existam importantes links entre a carteira de produtos da Cresol e estratégias de mitigação/adaptação, ainda há espaço para potencializar tais sinergias para mitigar uma possível nova fonte de risco e para aumentar a capacidade adaptativa dos clientes.

Palavras-chave: microfinanças verdes; mudança do clima; políticas públicas rurais; Pronaf; Cresol.

\section{Microfinanzas verdes: el caso del Sistema Cresol en la región Sur de Brasil}

El cambio climático que hasta hace poco parecía un lujo intangible para el sector de las microfinanzas, ahora parece ser crucial para el futuro del sector. Debido a la baja capacidad adaptativa, millones de clientes de microfinanzas de todo el mundo serán los más vulnerables al cambio climático. Adaptando el análisis de Agrawala y Maelis (2010 ) en Nepal y Bangladesh al contexto brasileño, este estudio cualitativo inductivo evalúa posibles sinergias entre MF y temas de MC, así como las estrategias que se pueden mejorar para reducir las vulnerabilidades de MC en el nivel micro/institucional. Por lo tanto, se investigó el segundo más grande programa de microcrédito rural de Brasil, el Sistema Cresol de Cooperativas de Crédito Rural con Interacción Solidaria. Aunque existan importantes vínculos entre la cartera de productos de Cresol y estrategias de mitigación/adaptación, hay todavía margen para mejorar estas sinergias para mitigar una posible nueva fuente de riesgo y aumentar la capacidad de adaptación de los clientes.

Palabras-clave: microfinanzas verdes; cambio climatico; políticas públicas; Pronaf; Cresol.

\section{Introduction}

Scientists claim that, by the end of this century, mean surface air temperature in Brazil could increase by up to $6{ }^{\circ} \mathrm{C}$, and trigger significant changes in the climate as we know it today (PBMC, 2013a). As conditions worsen, microfinance clients, at the bottom of the wealth pyramid and with limited adaptive mechanisms in hand, are increasingly vulnerable and exposed to climate change. The natural resources they rely on for their livelihoods, their old farming techniques, their homes and assets will be severely affected by extreme weather events making it harder for them to adapt to a new climatic context. From a microfinance point of view, the lack of sound coping mechanisms to respond to such changes will likely lead to widespread default tides among clients, and, ultimately, threaten solvency and liquidity of microfinance institutions' (MFI) portfolios. For many years, climate change actions, in particular adaptation strategies, seemed an intangible luxury for microfinance providers (Mckee, 2008). Today, however, "climate proofing" microfinance and its products appears to be essential for the future of the industry, in particular for those MFIs operating in rural areas (Mckee, 2008:37). In addition, due to the cross-sectoral and multidimensional traits of climate change, a myriad of actors from various levels and sectors will need to be engaged in the promotion of initiatives to mitigate its impacts, and so will MFIs (Forcella, 2013).

The combination of these two realms is particularly relevant to Brazil (Moser and Gonzalez, 2014). On the one hand, home to the "world's lungs", Brazil stands as a prominent actor in the fight against climate change and, at the same time, as victim of its adversities. In 
fact, the Amazon rainforest plays central role in the maintenance and conservation of natural ecosystems all over South America [e.g. through rainfall regimes] (Chou et al., 2011), and any alteration in that system would affect climatic patterns throughout the continent (Huntingford et al., 2013). On the other hand, favoured by governmental actions, the Brazilian microfinance sector experienced an exponential growth in recent years (Gonzalez, Piza and Garcia, 2009). Therefore, the marriage of these two sectors offers an intriguing and overlooked distribution channel for adaptation and mitigation strategies for the poorest segments of Brazil's society.

As part of a series of pilot-case studies conducted by Moser and Gonzalez (2014) on green microfinance in Brazil, this inductive qualitative study seeks to adapt previous analysis derived from Agrawala and Maëlis (2010) in Nepal and Bangladesh to the Brazilian context. Guided by the general questions: 1) how are products and services offered by a MFI linked to climate change actions; and, 2) how can microfinance actions be bolstered to take better considerations of climate change vulnerabilities?, it seeks to examine potential linkages between products and programmes offered by a Brazilian MFI and localised adaptation/mitigation strategies as well assess what strategies can be harnessed to better respond to specific climate change vulnerabilities or yield potential benefits. To do so, we investigated the case of the second largest rural microcredit programme in Brazil, Sistema Cresol de Cooperativas de Crédito Rural com Interação Solidária (Cresol System of Rural Credit Cooperatives with Solidarity Interaction).

\section{Literature review}

Initiatives in the context of climate change fall under two main categories, mitigation and adaptation. The first refers to actions that are aimed to reduce or eliminate entirely atmospheric concentrations of greenhouse gases (GHG) and/or ensure that carbon sinks do not become sources of emissions [e.g. deforestation] (Vijayavenkataraman, Iniyan and Goic, 2012), and its results are usually realised from the middle to the long run. Unlike mitigation, adaptation refers to short, medium and/or long run measures designed to reduce vulnerability and susceptibility of communities, individuals and countries to climate change impacts. Furthermore, adaptation actions seek to realise benefits arising from climate change (Brooke, 2008).

To date, however, MFIs have focused primarily on GHG mitigation through the financing of clean energy such as solar lanterns and systems, improved cooking stoves and biodigesters, as it is true for Sewa Bank and Selco in India, and Grameen Shakti in Bangladesh (see, for instance, Mckee, 2008; Rippey, 2012; Agrawala and Maëlis, 2010; Dowla, 2009). The Inter-American Development Bank (IDB), through the EcoMicro programme, provides technical training to MFIs based in Latin American and the Caribbean, helping them develop green finance products such as facilitating access to clean and efficient energy sources by clients. Moreover, several banks and investment funds such as the HSBC, Spandana and Credit MicroEnergy established partnership with local MFIs to offer green energy microloans to low-income households (Mckee, 2008; Allet, 2013a). 
Nevertheless, microfinance institutions are also a compelling vehicle in the delivery of adaptation strategies to the poor (Agrawala and Maëlis, 2010). Green microfinance scholars argue that MFIs can help families build and diversify their asset base and sources of income, as well as enhance long-term coping mechanisms such as savings schemes and microinsurance (Hammil et al., 2008; Mckee, 2008). At the same time, MFIs are imbued in strategic position to disseminate information about climate change related risks and to influence clients' behaviour towards adaptation initiatives (Agrawala and Maëlis, 2010; Dowla, 2009; Hall et al., 2008). Besides, MFIs can develop debt flexibilisation and disaster relief plans to deal with large-scale natural disasters and diseases outbreak (Dowla, 2009). Finally, MFIs can be used by international donors and governments as channel to deliver adaptation strategies to millions of low-income individuals and households worldwide (Agrawala and Maëlis, 2010).

A unique example of microfinance actions on the adaptation front comes from Cambodia. As an attempt to mitigate recurrent natural disaster related losses, in particular from floods and drought events, to poor rural communities in the village of Samaki, a local NGO, Save the Earth Cambodia, helped the community create the Micro-Insurance Facility (MIF) (Bian, 2011). Through a revolving fund, the community-led pilot project provides productive microloans at a minimum of US $\$ 30$ to poor rural women. In addition, all dividends and reserve funds are reinvested in rice stock as a protection mechanism against harvest shocks and food shortage. According to Forcella (2011), albeit some adjustments need to be considered, the MIF helped increase the community's resilience and adaptive capacity to cope with natural disasters mainly by fostering savings and local project ownership, building up clients' asset base and promoting diversification of income sources.

At the institutional level, an MFI also can estimate its carbon and ecological footprint in order to devise ex-post carbon offset and more eco-friendly actions such as reduce waste and paper use (Rippey, 2012). It can also promote training and capacity building for its personnel and clients on issues related to climate change impacts and initiatives (Rippey, 2012).

In fostering adaptation and mitigation strategies, it is likewise imperative for MFIs to establish strategic partnerships. The smallest MFIs, in particular, are those who can mostly benefit from such partnerships (Rippey, 2012; Dowla, 2009). For example, partnering with local home solar panel providers can reduce end-user prices and maintenance service costs; working in conjunction with local NGOs to implement adaptation initiatives can benefit entire communities and serve as potential funding source to "green" MFIs, such as the case of the MIF in Cambodia; liaising with insurance companies to provide microinsurance can protect clients from climate-related losses, and so forth.

Nevertheless, some dilemmas should be considered in promoting microfinance efforts in this terrain. While microfinance seem to thrive in the provision of financial and non-financial services to the economically active poor, they struggle to reach the poorest of the poor (Cull, Dermigüç-Kunt and Morduch, 2009:179), who are, after all, the most vulnerable to climate change. In addition, MFIs will have to find a balance between the short-term development needs, typical of microfinance, and the long-term commitments in fostering adaptation 
and mitigation actions (Hammil et al., 2008; Rippey, 2012). Moreover, microcredit may, in some cases, increase the debt burden of clients (see, for instance, Taylor, 2012), lowering further their adaptive capacity. Also, as MFIs climate proof their product envelopes and create new skills in this field they are increasingly adding up costs that can compromise their financial performance, as well as at risk of mission drift (Allet, 2013b; Forcella, 2013). Lastly, a "climate proof" MFI would need additional competencies that numerous MFIs lack (Rippey, 2012). Therefore, microfinance providers in projecting its actions on the climate change front will need to weigh up between costs and benefits inherent in the promotion of adaptation and mitigation actions to their clients, and also bear in mind that microfinance is by no means a panacea.

\section{Methodological approach}

As discussed earlier, the main objectives of this inductive qualitative study are twofold: 1) assess eventual synergies between a MFI's product envelope and localised climate change actions; and, 2) actions that can be bolstered in order to take better account of major site-specific climate change impacts or reaping eventual advantages. In order to facilitate understating and provide further insight into the subject matter, we relied on the case study design as research method provided by Robert Yin. To the author, "a case study is an empirical inquiry that investigates a contemporary phenomenon within its real-life context, in particular when the boundaries between phenomenon and context are not clearly evident" (Yin, 1994:13) ... and may provide a distinct advantage when "a how or why question is being asked about a contemporary set of events over which the investigator has little or no control" (Yin, 1994:9). In this fashion, we believe this research project fits in Yin's case study method conception as i) green microfinance in the studied context is a contemporary event in which ii) we have little or no control and iii) our research questions are of a "how" nature.

\subsection{Data collection}

Drawing on a variety of information and data stemming from sources such as financial reports, interviews, and field observation, this study has reviewed thirty-eight programmes, products and services offered by Cresol in recent years, usually for the period 2012-13. This process resulted in a list of products further analysed in light of the theory guiding green microfinance. In addition, data from the Mix Market platform were also used for the purpose of this study. This qualitative study also applied semi-structured interviews during field research.

We have identified five main social groups within Cresol considered relevant for our investigation. These include: the president, programme managers, branch managers, credit analysts and clients. The President is the highest management level within the Cresol System and chairs the steering committee. Likewise, programme managers at Cresol's headquarters 
are integral parts of the steering board, and as such, participate in the setting up of business strategies and strategic planning. Branch managers, as the name suggests, are in charge of specific branches, whereas credit analysts are the point of contact between clients and Cresol, as well as responsible for credit portfolio management within branches. Lastly, clients are smallholder farmers that benefits from Cresol's lending programmes and other non-financial services.

This process was followed by field research at Cresol's headquarters in the city of Francisco Beltrão in the state of Paraná, Southern Brazil, whereby we carried out semi-structured interviews, field observation as well as collected relevant documents. Thirteen respondents participated in the interviews: the president, three national managers, one branch manager, one credit analyst, and seven clients. For each identified social group we applied semi-structured questionnaires commensurate with its activities, experiences and contextual perception of the subject matter. For instance, to the president and programme managers, we designed questions associated with the overall design, administration, and performance of products and programmes offered by Cresol during hazardous weather events-e.g. programmes aimed to reduce exposure/vulnerability of clients to extreme climatic events; coping mechanisms against losses arising from such events, and so forth. To branch managers and credit analyst, we posed questions related to their perceptions over client's degree of exposure to weather extreme events and concrete actions they receive from Cresol amidst such events. At last, we asked clients to share their own experiences with respect to eventual weather-related losses they have incurred, and their customary coping mechanism against such shocks. Interviews' length varied from fifteen minutes, as for clients, to one hour for programme managers and the president of the Cresol System.

After reviewing the documentation and transcribing data from interviews, we have proceeded with the identification of localised climate change impacts, as well possible advantages, most relevant for the socioeconomic context where Cresol operates in. Then, the thirty-eight programmes, services and products offered by Cresol were clustered into specific categories to reflect sectoral focus of activities. Among these are: technical assistance/information transfer; payment services; savings and current account; disaster relief/preparedness; housing; forestry/agroforestry/renewable energy; employment and income generating activity; education; and, health. In particular cases, a single programme may fall into more than one category.

This process was succeeded by the analysis of the interface between Cresol's product envelope and localised climate change impacts, as proposed by Agrawala and Maëlis (2010). More specifically, the data were compiled into four categories: indirect link, direct link, climate proofing, and no link. Albeit not explicitly linked to adaptation and mitigation actions, indirect link category refers to those programmes which contribute to build up or diversify the asset base of clients and, therefore, wind up increasing their adaptive capacity against climate change impacts. Likewise, direct link products, as the name suggests, are explicitly designed to help clients lower their vulnerability/exposure to weather shocks and enhance their resilience in view of eventual weather-related impacts. Climate proofing, meanwhile, refers to 
those programmes which will need to take structural adjustments so as to take better account of climate change vulnerabilities. Lastly, no link activities have neither direct nor indirect connection with adaptation and/or mitigation initiatives. As for sectoral activities, in particular cases, a single programme may fall into more than one category.

\section{Analysis and discussion of results}

\subsection{The Cresol System: geographic context, products, and climate change impacts}

The Cresol System of Rural Credit Cooperatives with Solidarity Interaction [hereinafter referred to as Cresol System or simply Cresol] was established in 1996 in the state of Paraná, southern Brazil, as an attempt to provide credit and other financial and non-financial services to smallholder farmers in the region. Soon after, it has expanded to the state of Santa Catarina, and more recently, to Minas Gerais and Espírito Santo. Cresol, managed entirely by member farmers, is composed of three institutional structures: Central Cresol Baser, Services Regional Bases, and the Singular Cooperatives. Central Cresol Baser is the central cooperative acting as intermediary between the affiliate cooperatives and the Central Bank of Brazil (CBB). Also, it is responsible for the overall oversight and political representation of the System at large, as well as credit and service management. Services Regional Bases are service cooperatives aggregating singular cooperatives in the localities they operate. They offer, in particular, training, accounting, IT and other services related to rural credit activities to local affiliate Singular Cooperatives. The latter, in turn, act directly with smallholder farmers, facilitating and guaranteeing rural credit and service access.

Cresol operationalises several public lines of rural credit such as the National Programme to Strengthening Smallholder Farming (Pronaf), Bank of Brazil (BB) and the National Bank for Economic and Social Development (BNDES), which combined make up about $70 \%$ of its total disbursements. The remaining loans are financed out of Cresol's own resources collected from members' savings and spreads on official lines. Own resource loans are designed to complement official lines of credit, in particular, uncovered non-productive financing areas such as housing, car, and personal loans. According to the branch manager interviewed, official credit lines have, on average, a $2 \%$ annual interest rate, whereas own resources financings apply a $1.7-2.2 \%$ monthly interest rate.

Cresol Baser ranks as the second largest rural microfinance provider in Brazil and is the major rural MFI in southern Brazil. In 2013, alone, Cresol Baser had US\$588 million in assets and provided nearly US\$600 million in loans to 101,527 member clients throughout its 200 branches in the states of Paraná, Santa Catarina, Minas Gerais and Espírito Santo (Mix Market, 2014). Of the total loan disbursements, about US $\$ 225$ million were microcredit, i.e. loans of up to US $\$ 6,149$, delivered in 133,000 operations being $42 \%$ of them of up to US $\$ 798$ (Central Cresol Baser, 2014). 
Most villages Cresol operates in are covered by Atlantic Forest, a terrestrial biome spanning over $1,110 \mathrm{~km}^{2}$, in particular along the coast of Brazil (IBGE, 2004). The Atlantic Forest has several micro-regions within it, varying from tropical and subtropical moist/dry broadleaf forests, to savannas and mangrove forests. This endemic biome also has diverse weather and pluviometic regimes with its coastal portion, in particular, characterised by more abundant rainfalls.

Southern Brazil has faced abnormal drought and flood events over the last decade, with significant losses to its agricultural production (Sousa Junior, Sausen and Lacruz, 2010). In 2005, for example, intense seasonal drought caused damage estimated at US\$2.5 billion, affecting largely dairy cattle production (Agroline, 2009). In 2008, in the state of Santa Catarina, torrential rains poured, in a two-day span, more than twice as much as the expected monthly-rainfall, causing severe inundation and landslides, and inflicting several life and asset losses, as well as impacting on food production (Ceped-UFSC, 2012). In December 2013, the south-eastern states of Espírito Santo and parts of eastern Minas Gerais were brought to their knees when a torrential rain triggered massive flooding that inflicted myriad life and asset damages.

Such differences in monthly average discharge and weather regimes in southern and south-eastern states have been associated with periods of La Niña and El Niño (Yamashiki et al., 2010). These are leading climate modes affecting weather patterns in South America (Mcglone and Vuille, 2012). El Niño events have usually been related to increased precipitation indices along the coastal areas of southern Brazilian states, whereas La Niña have tended to produce the opposite effect, i.e. drought events (Mcglone and Vuille, 2012).

These variations in climate patterns and precipitation are likely to be intensified under future global climate change scenarios. Scientific projections suggest, in fact, consistent pattern of changes to seasonal variations in temperature and rainfall distribution in southern and parts of south-eastern Brazil (Marengo et al, 2009, 2010). According to the Brazilian Panel on Climate Change (PBMC), until 2040 a slight increase in temperature varying between $0.5^{\circ} \mathrm{C}$ in the austral summer and $1^{\circ} \mathrm{C}$ during winter is likely to occur (PBMC, 2013a). In the same period, rainfalls are expected to increase by 5 and $10 \%$ in winter and summer, respectively. By the middle of the century [2041-2070], temperatures will rise by 1.5 and $2^{\circ} \mathrm{C}$ and precipitation by 15 and $20 \%$. As the century turns, temperatures are likely to increase by $3^{\circ} \mathrm{C}$ during winter and $2.5^{\circ} \mathrm{C}$ in austral summer, whereas rainfall by 25 and $30 \%$ during winter and summer, respectively. Abnormal seasonal drought events associated with La Niña are also expected to increase in the future in parts of inland Southern Brazil. Increased temperature coupled with such changes in the climate cycle will likely induce a "tropicalisation" of Southern and parts of South-eastern Brazil by the end of the century (PBMC, 2013b).

Table 1 ranks key site-specific climate change vulnerabilities and eventual benefits expected for the areas in which Cresol operates. Climate change will be a key downward driver affecting the economies of southern and south-eastern Brazilian states as they are major agricultural producers. Production of milk and meat, as well as rice, maize and soya bean will likely be reduced by increased temperatures and higher precipitation variation [varying from 
drought to floods], which will, ultimately, impact on farmers' income and bring about food security concerns. In addition, as past instances have shown (see, for instance, Sousa Junior, Sausen and Lacruz, 2010; Mcglone and Vuille, 2012), drought episodes associated with La Niña may exacerbate stresses related to irrigation and water, affecting pasture based production systems and rice crops, widely practiced by local farmers. All these factors lead agriculture/livestock to be ranked at the top in terms of vulnerability, urgency and importance for the regional socioeconomic dimension, in particular, for Cresol's clients.

Human health is ranked next as second major climate change-related vulnerability. Greater incidence of endemic infectious and vector-borne diseases as well as heat waves, life losses during landslides and flooding, and food insecurity as a result of reduced crop production, will affect human health in southern and south-eastern Brazilian states. This is followed by water resources, in particular, because, on the one hand, greater rainfall distribution and river runoff will impact positively the regional water availability. On the other hand, however, mixed precipitation pattern outcomes, particularly in South-eastern Brazil, varying from state to state, sub-region to sub-region, village to village, will have both negative and positive impacts on water access/availability.

Climate change may also bring advantages to farming. For example, a climate change-induced "tropicalisation" and increased temperatures in South and Southeast Brazil may reduce frost damages and favour production of tropical crops such as coffee and sugarcane (PBMC, 2013b). To this regard, the PBMC (2013b) argues that such climate change-induced benefits can add up $2 \%$ to the GDP in southern states by the middle of the century.

Table 1

Resource ranking of key climate change priorities, vulnerabilities and eventual benefits for areas where Cresol operates

\begin{tabular}{|c|c|c|c|c|c|}
\hline $\begin{array}{l}\text { Climate Change } \\
\text { Forecast }\end{array}$ & $\begin{array}{c}\text { Weather-Related } \\
\text { Events }\end{array}$ & $\begin{array}{l}\text { Major Socioeconomic } \\
\text { Impacts }\end{array}$ & $\begin{array}{l}\text { Timing of } \\
\text { Impact }^{\mathrm{a}}\end{array}$ & $\begin{array}{l}\text { Importance of } \\
\text { Resource }^{\mathrm{b}}\end{array}$ & $\begin{array}{c}\text { Major } \\
\text { Benefits }\end{array}$ \\
\hline Higher rainfall & $\begin{array}{l}\text { Flooding and } \\
\text { heavy rains }\end{array}$ & Agriculture/Livestock & & & $\begin{array}{l}\text { Reduced } \\
\text { frost } \\
\text { damages }\end{array}$ \\
\hline $\begin{array}{c}\text { Increased } \\
\text { temperature }\end{array}$ & $\begin{array}{c}\text { Drought } \\
\text { Increased river } \\
\text { runoff }\end{array}$ & Human health & Short-medium & High & $\begin{array}{l}\text { Increased } \\
\text { tropical crop } \\
\text { production }\end{array}$ \\
\hline & Tropicalisation & Water resources & & & $\begin{array}{c}\text { Reduced } \\
\text { cold weather }\end{array}$ \\
\hline
\end{tabular}

Source: Based on PBMC (2013a, 2013b) and field observation.

Note: a. Short (201 1-40) - Medium (2041-70) - Long (2071-00). b. Importance of resource based on relevance for the socio-economic aspects of the region. 
With respect to Cresol's product envelope, we note that the great bulk of its financial services lie within Pronaf, with loans varying from short-term lending products such as Pronaf Custeio-intended to meet working capital needs of a single agricultural year-, Mais Alimentos (literally More Food)—to finance long-term investments—, to lines dedicated to empowering women and youth.

Under Pronaf Custeio, there exist three lending modalities: (i) loans of up to R $\$ 10,000$ (US $\$ 4,098$ ) at $1.5 \%$ annual interest rates, (ii) loans from $\mathrm{R} \$ 10,000$ to $\mathrm{R} \$ 30,000$ (US $\$ 12,300$ ) at $3 \%$ annual interest rate, and (iii) loans ranging from $\mathrm{R} \$ 30,000$ to $\mathrm{R} \$ 100,000$ (US $\$ 41,000$ ) at 3.5\% annual interest rate (Ministério do Desenvolvimento Agrário, 2013). Also, loan terms may vary between 1 and 3 years depending on the typology of the financed activity. On the other hand, Pronaf Mais Alimentos has a 10-year loan term and is divided into two categories, i.e. loans of up to $\mathrm{R} \$ 10,000$ at $1 \%$ annual interest rate, and loans from $\mathrm{R} \$ 10,000$ to $\mathrm{R} \$ 150,000$ (US\$61,490) at 2\% annual interest rate. Cresol also has specific microcredit programmes financed via funds stemming from the BNDES, Pronaf and own resources (Central Cresol Baser, 2014).

The Cresol System also seeks to realise synergies with governmental programmes and public policies such as the School Feeding Programme (PNAE), Food Acquisition Programme (PAA), The Family Farm Support Price Programme (PGPAF), Technical Assistance and Rural Extension (Ater), and the Guarantee Programme for Agriculture and Livestock Activities (Proagro). The latter consists of a subsidised crop insurance linked to Pronaf Custeio loans. It is aimed at protecting smallholder farmers against eventual shocks and related harvest losses during an agricultural year, in particular in the harvest phase. The insurance claim is triggered whenever crop failures are identified, following individual field loss assessments, and is meant to cover instalments due commensurate with the percentage of alleged crop losses. In addition, Proagro Mais (Plus), also called SEAF (Insurance of Smallholder Farmers), pays an additional lump sum-up to R\$ 5,000 (US\$2,049) in the 2013-14 agricultural year-to policyholders so that they can cope with immediate livelihood needs. While Proagro Mais is compulsory for Pronaf Custeio loans, they are voluntary for Pronaf's investment credit lines (Cardenas, 2013). Lastly, for both investment and operating lending modalities, Proagro detracts a 2\% fee from each Pronaf's instalment (Ministério do Desenvolvimento Agrário, 2012).

In order to provide an additional insurance service to protect areas uncovered by the government's Proagro, Cresol has established its own insurance company, namely Cresol Seguros. Some examples of insurance policies provided by Cresol Seguros include: housing, life credit, machinery, car, livestock, frost and hail insurances. In addition, Cresol, through Pronaf, provides specific loans for the financing of more eco-friendly practices as it is the case of Pronaf Forest, Eco and Agroecology. The former finances agroforestry projects, Pronaf Agroecology finances investments in agroecological and/or organic production systems; whereas Pronaf Eco provides funding for techniques that minimise impact and degradation of local environment caused by rural activities. Some activities financed under these lines are: improved water systems, renewable energy and more eco-friendly agricultural infrastructures/ technologies, organic production systems, silviculture and agroforestry systems. 
On the knowledge transfer and community empowerment front, the Programme of Community Agents of Development and Credit (PACDC) aims at encouraging members to participate actively in the management of Singular Cooperatives as well as at boosting discussion over important issues such as environmental protection and local development (Central Cresol Baser, 2014). Other financial and non-financial services provided by Cresol are current and savings account, education, check and credit card provision, pension and other payment services, mobile phone services, and the gender and generation empowerment programme. More recently, Cresol established a civil society organisation [a.k.a. Oscip under the Brazilian regulatory framework], the Solcredi, in order to provide its members no longer engaged in agricultural activities, and thus, ineligible to access Pronaf funds, with urban micro-loans. Table 2 reports all products, programmes and services provided by the Cresol System of Rural Credit Cooperatives with Solidarity Interaction as of January 2014.

Table 2

List of products, services and programmes offered by the Cresol System

\begin{tabular}{|c|c|c|c|c|}
\hline Lending programmes & $\begin{array}{c}\text { Products related } \\
\text { to environmental } \\
\text { variables }\end{array}$ & $\begin{array}{l}\text { Synergies with } \\
\text { governmental } \\
\text { programmes }\end{array}$ & $\begin{array}{l}\text { Other banking and } \\
\text { non-banking services }\end{array}$ & Disaster relief products \\
\hline $\begin{array}{l}\text { Pronaf Custeio } \\
\text { Pronaf Mais Alimentos } \\
\text { Pronaf Agroindustry } \\
\text { Pronaf Women } \\
\text { Pronaf Youth } \\
\text { Microcredit } \\
\text { Solcredi }\end{array}$ & $\begin{array}{l}\text { PACDC } \\
\text { Pronaf forest } \\
\text { Pronaf Eco } \\
\text { Pronaf Agroecology }\end{array}$ & $\begin{array}{l}\text { PGPAF } \\
\text { Pnae } \\
\text { PAA } \\
\text { Ater } \\
\text { Proagro } \\
\text { Seaf }\end{array}$ & $\begin{array}{l}\text { Current /savings account } \\
\text { Education } \\
\text { Credit card } \\
\text { Check } \\
\text { Pension payment } \\
\text { Payment services } \\
\text { Mobile phone services } \\
\text { Habitasol } \\
\text { Gender and generation }\end{array}$ & $\begin{array}{l}\text { Credit Life Insurance } \\
\text { Collective Insurance } \\
\text { Life Insurance } \\
\text { Car Insurance } \\
\text { Business Insurance } \\
\text { Motorbike Insurance } \\
\text { Multi-risk insurance } \\
\text { Property Insurance } \\
\text { Machinery Insurance } \\
\text { Hail and Frost Insurance } \\
\text { Livestock Insurance }\end{array}$ \\
\hline
\end{tabular}

Source: Authors.

When refined into sectoral focus of activities, we note that albeit variegated, Cresol's product envelope focuses primarily on employment and income generating activities, as well on disaster relief and preparedness, and, combined, make up $61 \%$ of the total. Insurance schemes and productive loans all fall within these two categories. Next are savings/current account schemes and related services, accounting for $9 \%$ of Cresol's product envelope. These are followed by products aimed at the provision of technical assistance and information transfer, as well payment services totaling 7\% of total. Right next are health and education related products making up 5\% of total products, as well as (agro)forestry and renewable energy with $4 \%$. Lastly, housing products constitute $2 \%$ of Cresol's products. 
Figure 1

Programmes and products financed by Cresol by sectoral categories

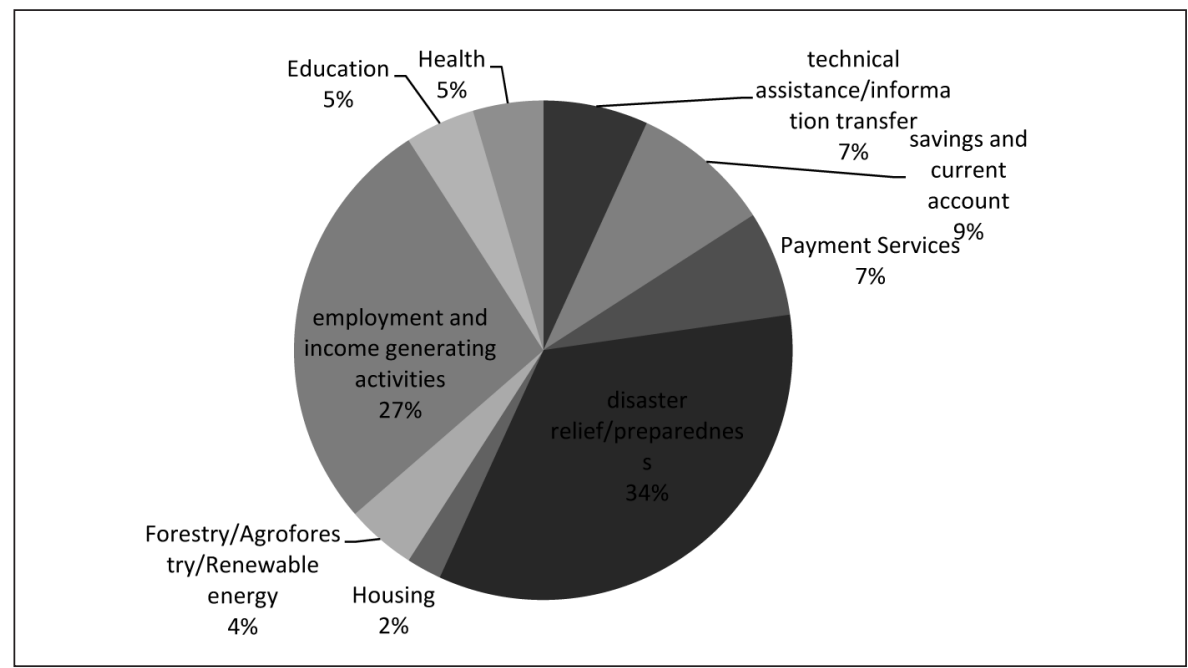

Source: Authors.

\subsection{Links to climate change adaptation and mitigation initiatives}

There exist significant overlaps between major climate change-related vulnerabilities identified in table 1 and Cresol's main areas of activities shown in Figure 1. Products that build clients' adaptive ability against shocks such as those under employment and income generating activities, coping mechanisms under disaster relief and preparedness, as well as health -related products will all be valuable adaptation resources if scientific predictions over abrupt increases in temperatures materialise. Likewise, products related to the provision of more eco-friendly practices and techniques also constitute laudable mitigation tools.

However, as Agrawala e Maëlis (2010) argued, products which a priori might seem plausible from an adaptation/mitigation viewpoint might end up increasing clients' vulnerability and thus lead to maladaptation. Financing maize crops for silage, a practice widely adopted by Cresol's clients, leaves clients greatly exposed to heat-related yield losses, for instance. On the other hand, activities apparently disconnected from these realms might eventually enhance clients' ability and resilience to cope with climate change, as it is true for savings schemes. Therefore, a more nuanced approach is needed if we are to systemically assess Cresol's product envelope in light of adaptation and mitigation actions.

Figure 2 illustrates eventual linkages between products, programmes and services offered by Cresol and climate change actions commensurate with key vulnerabilities shown in table 1 . Accordingly, $13 \%$ of Cresol's product envelope is directly and explicitly linked to 
adaptation and/or mitigation initiatives. Under direct link are crop insurance schemes such as Proagro and Proagro Mais; lending programmes aimed at greener infrastructure/practices, for example, Pronaf Agroecology, Pronaf Forest, Pronaf Eco; the PACDC; and technical assistance provision or Ater.

Under this category, Proagro and Proagro Mais merit particular attention. As climate change-related harvest losses soar in the future, these insurance schemes will constitute a ready and sound disaster relief tool for Cresol's clients. By taking Pronaf Custeio loans to finance agricultural inputs for maize production [an extremely heat sensitive crop], for instance, Cresol's clients are compulsory tied to Proagro and Proagro Mais. In addition to protecting farmers against losses, these two programmes guarantee solvency to Cresol's portfolio once covariant risks are transferred to the government. Albeit not perfect substitutes for what farmers would have earned under a normal harvest cycle, Proagro and Proagro Mais were considered, by all respondents, a commendable buffer against incurred crop losses.

Other identified programmes and products under direct link also will have an essential role in enhancing client's adaptive ability to cope with climate change impacts in the near-future. For example, on the knowledge transfer/sharing front, the PACDC organises regular meetings and assemblies with member clients to discuss topics pertinent to more sustainable cropping practices and technologies. For example, some interviewed clients argued that one major reason they have opted for polyculture ${ }^{1}$ crops was mostly due to PACDC's sessions. Similarly, programme managers emphasised the role played by Cresol in providing financing for improved irrigation/water infrastructures-e.g. water wells and aquaculture-which is a major issue during times of drought. Besides, (agro)forestry, silviculture, and silvipasture projects under Pronaf Forest, Agroecology, and Eco are important actions to mitigate soil erosion and landslides while at the same time producing sinks for $\mathrm{CO}_{2}$ and equivalents.

Likewise, $46 \%$ of total products are implicitly and indirectly related to adaptation and/ or mitigation. All financial services aimed at employment generating activities-e.g. Pronaf Custeio and Mais Alimentos, Pronaf Youth and Women, Solcredi, Microcredit, Habitasol, savings schemes-, as well as those providing coping mechanisms against shocks [think of the various insurance schemes], fall into indirect link. Among these, Pronaf Custeio represents the vast majority of lending products in terms of volume and credit operations, and as such, will constitute a handy adaptation instrument embodied in Cresol's product envelope. This is because productive loans under Pronaf Custeio are automatically protected against climate-related losses by Proagro, which by and large, do not imply any additional cost and/or risks to the portfolio of the Cresol System. Moreover, the Solcredi, aimed at urban microcredit provision,

\footnotetext{
${ }^{1}$ By altering diverse crops along the agricultural year, polyculture cropping, such as intercropping, helps reduce the incidence of crop diseases (and thus the use of fertilisers) and guarantee that soil remains rich in nutrients necessary for healthy harvests, which in turn, increases productivity and, ultimately, yields. Besides, polyculture crop systems allow farmers to diversify income sources, and therefore, are important risk transfer mechanisms.
} 
will have a stake in encouraging diversification of income sources and employment activities toward areas least exposed to climatic risks.

Along all these products identified under indirect link category, credit analysts may perhaps be key actors in nudging income and employment diversification and promoting knowledge sharing. Being close to the needs of farmers, and in possess of local knowledge, credit analysts are in strategic position to influence credit allocation and diffuse information about climate change initiatives (see, for example, Agier (2012) on the role of credit agents). Their role within Cresol will be enhanced by the Segmentation Project which requires that all loan disbursements be completely operationalised through credit analysts. More specifically, they will be responsible for assisting members prior and during the entire loan term, as well as in charge of identifying areas to be realised. Credit analysts also participate actively in the evaluation of debt restructuring and rescheduling.

Non-productive loans for more resistant houses such as Habitasol and savings schemes will also help enhance resilience of clients ahead of climate extreme events. Direct and indirect link categories, combined, account for 59\% of all Cresol's products and constitute what Agrawala and Maëlis (2010) coined "win-win" products, i.e. which as currently structured would automatically contribute to adaptation and/or mitigation to climate change.

These are followed by "no link" category which makes up 17\% of total and includes payment services, check and credit card provision, and mobile service payments. Lastly, there is the "climate proofing" category with $24 \%$ of Cresol's product envelope share. Among these are (i) insurance schemes such as housing, business, machinery, livestock, frost and hail; (ii) lines of credits under Pronaf such as Eco, Forest, Agroecology as well as Pronaf Custeio; (iii) technical assistance (Ater), and, (iv) the Programme of Community Agents of Development and Credit. These are products, services, and programmes which will need to take better account of site-specific climate change vulnerabilities in order to enhance client's resilience and adaptive ability. Or also, in some cases, they will need to be restructured in order to better reap localised benefits and advantages arising from increased temperatures.

Business, livestock, housing and machinery insurance schemes fall into the "climate proofing" category (i) because they do not cover losses caused by major projected impacts such as droughts and floods, although some of them do provide additional coverage against windstorm-related losses. In addition, because the incidence of frost events are expected to decrease markedly in the future, insurance policies such as the frost \& hail will make less and less sense. Under (ii), projects financed through Pronaf Eco, Forest and Agroecology, remain very limited to date. With regard to this, an interviewed credit analyst argued that demand for green credit lines is indeed very small due to viability issues of eco-friendly projects. A forestry project would require several years of financial commitment and returns are earned on the long run, making clients inclined towards shorter-term financial products to meet more urgent and immediate livelihood needs.

Further, because no specific programme to encourage heat-tolerant or tropical crops is available, Pronaf Custeio-Cresol's lending powerhouse and thus most suitable financial product to achieve such a goal—falls into the "climate proofing" category. The fact that most 
Cresol's clients grow maize for silage, and that maize crops are greatly vulnerable to high temperatures and climate extremes such as drought, leaves clients extremely exposed to temperature oscillations. To interviewed clients maize was, in fact, considered the most vulnerable crop to climatic events, and most of them said to have already experienced partial and/or total maize harvest loss during previous drought events.

Right next (iii) is the technical assistance (Ater), in particular because of its under-provision and superficiality in addressing more sustainable practices. By way of example, interviewed clients said to have never received technical assistance from the Cresol System because this service is usually provided by agricultural input traders, which however, limit assistance to the proper use of fertilisers, chemicals, feeds, etc. This viewpoint was seconded by managers interviewed who did recognise the need to realise technical assistance provision. Lastly, (iv) the PACDC figures among "climate proofing" products particularly because it may need structural adjustments in order to fully grasp its potentials in directing clients toward climate change actions.

\section{Figure 2}

Categorisation of linkages between Cresol's products and climate change strategies

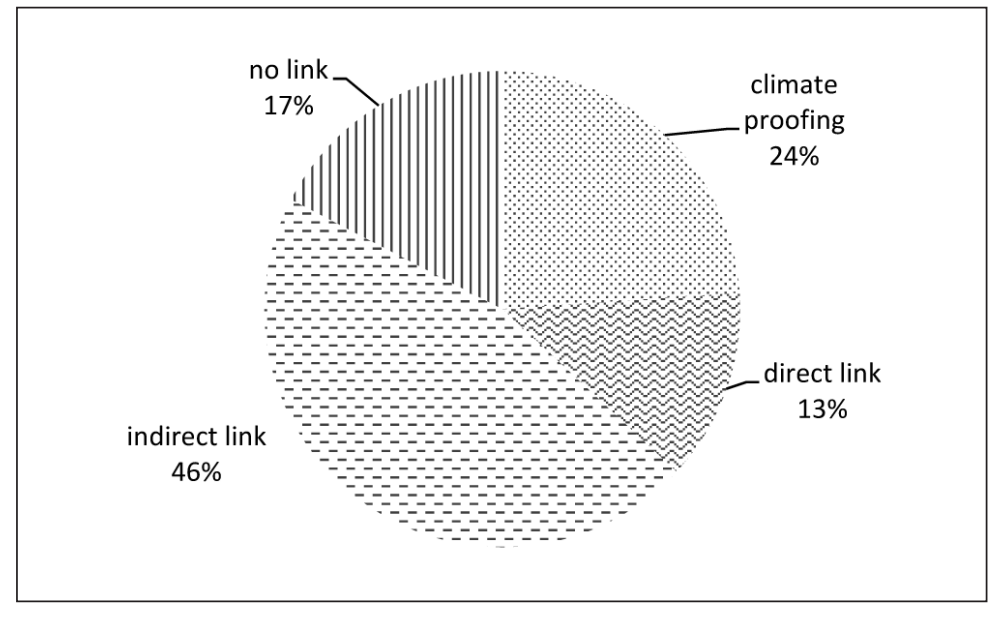

Source: authors

\section{Conclusion and recommendations}

This study sought to demonstrate that there already exist strong linkages between existing products, services and programmes offered by Cresol and adaptation, and to a lesser extent, mitigation initiatives. In fact, more than half of Cresol's product envelope fall into the "win -win" category, i.e. which as currently structured would automatically enhance the adaptive 
ability of clients to cope with climate change. This is the case of loans under Pronaf Custeio, the bulk of Cresol's lending practices, which are protected against climate-related losses by the governmental crop insurance, Proagro and Proagro Mais. Besides, covariant risks associated with Proagro insurance policies are transferred to the government, guaranteeing, to a certain extent, solvency of Cresol's portfolio.

Besides, through Pronaf green lines, Cresol provides its clients with loans for improved irrigation systems, helping them lower crop losses during drought periods. During interviews with clients, loans for improved water systems were indeed considered a major accomplishment done by Cresol. Also, the assemblies and community agents, under the PACDC, play pivotal role in promoting knowledge sharing on more sustainable agricultural practices. Likewise, the Segmentation Project will place credit analysts in strategic position to encourage employment and income diversification, and knowledge sharing on adaptation and/or mitigation initiatives. During weather shocks, savings schemes provide a significant coping mechanism, in particular, for poorest members. At last, non-productive loans for "climate proof" homes help increase client's resilience and thus their adaptive capacity to climate change.

The Cresol System, however, may consider deepening and scaling up such linkages and, in some cases, take structural adjustments in order to take better account of climate change impacts and, also, potential benefits stemming from global warming. In "climate proofing" its products, Cresol will, for example, need to take forward plans and perform risk management assessments in light of localised climate change vulnerabilities and risks. Such an approach will allow the Cresol System to set up ex-ante risk management plans in view of eventual losses stemming from increased climatic variability, as well as areas in which it may benefit from a warmer climate. At the same time, this will allow Cresol to incorporate tailored ex-post climate change initiatives into its strategic planning and day-to-day operations. To do that, though, Cresol will need to improve its data system collection, for instance, by mapping, on a more detailed and in-depth basis, sectoral lending allocation [e.g. livestock, agriculture, services, and so forth].

As noted earlier, about 70\% of Cresol's lending comes from official lines of credit, in particular, Pronaf. Forthcoming plans announced by Cresol's president during interviews aim to reduce to $40-60 \%$ the share of such official lines disbursements by 2015 . However, a trade -off will eventually emerge as own-resource crop loans will remain outside Proagro's regime, and thus, unprotected against climate-related harvest losses. Cresol will then need to forge new insurance schemes either to avoid default risks—once clients might probably struggle to fulfil its financial obligations-, or to sustain its member's income ahead of natural disasters, adding up additional costs to the System at large.

Cresol could therefore implement, through its insurance company, least costly and risky schemes such as the index based insurance bundled with own resource loans as alternative to Proagro. These are insurance policies whose payouts are triggered according to established local weather thresholds, or indexes, and hence, avoid problems related to individual misbehaviour such as moral hazard (Wang et al., 2013). In other words, weather-based insurances are indexed in localised climate patterns or trends-e.g. rainfall or temperature-recorded in 
a specific weather station over a certain period of time. From such observations, a threshold and a limit for that specific weather event are established so as to create a range for claim payments (Barnett and Mahul, 2007). Accordingly, whenever the threshold is exceeded policyholders get automatically paid the insurance claim up to the amount insured and to the established limit, and without the need for individual harvest loss assessments.

Likewise, other insurance policies-business, housing, machinery, frost and hail insurance schemes - could also be supplemented by such index-based insurance so that to provide coverage in areas most exposed to future climate change impacts [floods and drought]. To implement these, Cresol can also establish strategic partnerships with regional, national and/ or international actors engaged in the provision of such insurance schemes, as was the case of the area yield insurance for farm families in the state of Rio Grande do Sul (see Hazell et al., 2010:145).

Encouraging diversification from heat sensitive to more weather tolerant crops also will be of utmost importance to Cresol and its members both to lower crop failures and losses, as well as to allow clients to benefit from the "tropicalisation" of southern Brazilian states. Existing tools such as ATER, the PACDC, as well as credit analysts could be used to nudge members toward more sustainable practices and to foster local knowledge sharing on adaptability. For instance, disseminating information on more adapted cultivations for silage-e.g. sorghum and sunflower-as well as on more appropriate tropical crops-such as sugarcane and coffee; or promoting the exchange of clients' experiences on customary coping mechanisms during natural disasters such as droughts and floods. Moreover, Cresol can avail itself of the consistent body of research conducted by the Brazilian Agricultural Research Corporation (Embrapa) on drought and flood resistant crops (see, for instance, Tomich, Pereira and Gonçalves, 2004) to devise client-level crop adaptation actions.

There are also potentials for Cresol to realise synergies with other governmental programmes in view of the promotion of climate change actions, for instance, the Ater. To this regard, interviewed managers argued that there is already an attempt to internalise and improve technical assistance provision in parallel with Ater. Also, there is considerable scope to scale up credit lines designed to finance mitigation initiatives, such as Pronaf Eco, Forestry, and Agroecology, even though eventual incompatibilities might emerge between short-term livelihood needs and the long-term commitments required for mitigation actions.

Beyond client-level actions, Cresol could still undertake actions at the institutional level, for instance, reduce its carbon footprint by limiting paper use and waste. Also, the carbon credit market, through the Clean Development Mechanisms and/or the voluntary market, can offer an additional vehicle to capitalise funds to finance community/client level mitigation projects.

Finally, it must be borne in mind that albeit linkages between products offered by Cresol and climate change actions do represent important tools to reach out the rural poor in southern and south-eastern Brazilian states, which happen to be greatly vulnerable to a changing climate, they are certainly no panacea. Therefore, in embarking on a more proactive approach to climate change, Cresol will need to keep expectations realistic. 


\section{References}

AGIER, Isabelle. The role of credit officers in the performance of micro loans: evidence from Brazil. Economics of Transition, v. 20, n. 2, p. 271-297, 2012.

AGRAWALA, Shardul; MAËLIS, Carraro (Org.). Assessing the role of microfinance in fostering adaptation to climate change. OECD Environmental Working Paper n. 15, Paris, OECD, 2010.

AGROLINE. Estiagem no Sul: Secretaria sugere medidas emergenciais para pescadores e piscicultores, 2009. Available at: <www.agronline.com.br/agronoticias/noticia.php?id=1127>. Access on: Jan.15.2014.

ALLET, Marion. Why do microfinance institutions go green? Working Papers CEB, 2013b.

ALLET, Marion; HUDON, Marek. Green microfinance. Characteristics of microfinance institutions involved in environmental management. Working Papers CEB, 2013a.

BARNETT, Barry J.; MAHUL, Olivier. Weather index insurance for agriculture and rural areas in lower-income countries. American Journal of Agricultural Economics, v. 89, n. 5, p. 1241-1247, 2007.

BIAN, Cara. Weathering the weather: how climate change became the currency that transformed a vulnerable community. Phnom Penh: Seaglobe, 2011.

BROOKE, Cassandra. Conservation and adaptation to climate change. Conservation Biology Journal, v. 22, n. 6, p. 1471-1476, 2008.

CARDENAS, Ramiro R. Identification and assessment of financing mechanisms to support adaptation and mitigation to climate change at the smallholder coffee farm level - the case of Minas Gerais (Brazil). Belo Horizonte: E.D.E. Consulting, 2013.

CENTRAL CRESOL BASER. Relatório de atividades e balanço social 2013. Francisco Beltrão: Banco do Nordeste, 2014. p. 46.

CEPED-UFSC. Atlas brasileiro de desastres naturais 1990-2010. Volume Santa Catarina. Florianópolis: Ceped-UFSC, 2012.

CHOU, Sin C. et al. Riscos das mudanças climáticas no Brasil: análise conjunta Brasil-Reino Unido sobre os impactos das mudanças climáticas e do desmatamento na Amazônia. São Paulo: Inpe; Londres: MetOffice, 2011.

CULL, Robert; DEMIRGÜÇ-KUNT, Asli; MORDUCH, Jonathan. Microfinance meets the market. Journal of Economic Perspectives, v. 23, n. 1, p. 1-30, 2009.

DOWLA, Asif. Climate change and microfinance. Washington: Grameen Foundation, 2009.

FORCELLA, Davide. Microfinance and adaptation to climate change. In: UMM WORKSHOP, 10TH, 2013, Frankfurt.

FORCELLA, Davide. Preliminary assessment microinsurance facility for climate change adaptation. Save The Earth Cambodia, 2011. 
GONZALEZ, Lauro; PIZA, Caio T.; GARCIA, Daniel B. Sinergia entre microsseguro e microcrédito e o crescimento dos mercados no Brasil. Revista Brasileira de Risco e Seguro, v. 5. n. 10, p. 45-84, 2009.

HALL, Joan C. et al. The missing bottom line: microfinance and the environment. The Seep Network Social Performance Working Group Social Performance MAP, 2008, Washington, DC.

HAMMIL, Anne et al. Microfinance and climate change adaptation. IDS Bulletin, Institute of Development Studies, v. 39, n. 4, p. 113-122, 2008.

HAZELL, Peter et al. Potential for scale and sustainability in weather index insurance for agriculture and rural livelihoods. International Fund for Agricultural Development and World Food Programme. Rome, 2010.

HUNTINGFORD, Chris et al. Simulated resilience of tropical rainforests to $\mathrm{CO}_{2}$-induced climate change. Nature Geoscience, v. 6, n. 4, p. 268-273, 2013.

IBGE. Mapa de biomas e o mapa de vegetação do Brasil. Brasília: Instituto Brasileiro de Geografia e Estatística (IBGE), 2004.

MARENGO, Jose A. et al. Future change of climate in South America in the late twenty-first century: intercomparison of scenarios from three regional climate models. Climate Dynamics, v. 35, n. 6, p. 1073-1097, 2010.

MARENGO, Jose A. et al. Future change of temperature and precipitation extremes in South America as derived from the Precis regional climate modeling system. International Journal of Climatology, v. 29, n. 15, p. 2241-2255, 2009.

MCGLONE, Dana; VUILLE, Mathias. The associations between El Niño-Southern oscillation and tropical South American climate in a regional climate model. Journal of Geophysical Research: Atmospheres, v. 117, n. D6, p. 1984-2012, 2012.

MCKEE, Katherine. Microfinance: climate change connections. Development Outreach, Washington, v. 10, n. 1, p. 35-37, 2008.

MINISTÉRIO DO DESENVOLVIMENTO AGRÁRIO. Resumo plano safra 2012/2013. 2012. Available at: $<$ www.emater.tche.br/site/br/arquivos/area/credito_rural/MCR_12.pdf>. Access on: Jan.17.2014.

MINISTÉRIO DO DESENVOLVIMENTO AGRÁRIO. Resumo plano safra 2013/2014. 2013. Available at: < http://portal.mda.gov.br/portal/saf/arquivos/view/PRONAF/arquivos-tecnicos-plano-safra-13-14/Condi\%C3\%A7\%C3\%B5es_do_Cr\%C3\%A9dito_2013-2014.pdf > . Access on: Jan.17.2014.

MIX MARKET. Cresol market profile. Mix Market, 2014. Available at: <www.mixmarket.org/mfi/ central-cresol-baser $>$. Access on: Dec.13.2014.

MOSER, Rafael; GONZALEZ, Lauro. Green microfinance in Brazil: the case of Agroamigo, a Brazilian MFI. (forthcoming). RAE, FGV, 2014.

PBMC. Contribuição do Grupo de Trabalho 2 ao Primeiro Relatório de Avaliação Nacional do Painel Brasileiro de Mudanças Climáticas. Sumário Executivo do GT2. PBMC, Rio de Janeiro, Brasil, 2013b. p. 28. 
PBMC. Sumário executivo do volume 1 - base científica das mudanças climáticas. Contribuição do grupo de trabalho 1 para o $1^{\circ}$ relatório de avaliação nacional do painel brasileiro de mudanças climáticas. Volume Especial para a Rio+20. Rio de Janeiro: PBMC, 2013a. p. 34.

RIPPEY, Paul. Microfinance and climate change: threats and opportunities. In: KÖHN, Doris. Greening the financial sector. Berlin Heidelberg: Springer, 2012. p. 215-239.

SOUSA JUNIOR, Manuel; SAUSEN, Tania M.; LACRUZ, Maria S. Monitoramento de estiagem na região sul do Brasil utilizando dados evi/modis no período de dezembro de 2000 a junho de 2009. São José dos Campos: Inpe, 2010.

TAYLOR, Marcus. The antinomies of 'financial inclusion': debt, distress and the workings of Indian microfinance. Journal of Agrarian Change, v. 12, n. 4, p. 601-610, 2012.

TOMICH, Thierry R.; PEREIRA, Luiz G.; GONÇALVES, Lucio C. Alimentos volumosos para o período seco - I: silagem de girassol. Corumbá: Embrapa Pantanal, 2004. p. 30.

VIJAYAVENKATARAMAN, Sanjairaj; INIYAN, Sanjairaj; GOIC, Ranko. A review of climate change, mitigation and adaptation. Renewable and Sustainable Energy Reviews, v. 16, n. 1, p. 878-897, 2012.

WANG, Holly et al. Farmers' demand for weather-based crop insurance contracts: the case of maize in South Africa. Agrekon: Agricultural Economics Research, Policy and Practice in Southern Africa, v. 52, n. 1, p. 87-110, 2013.

YAMASHIKI, Yosuke A. et al. Recent SST trends and flood disasters in Brazil. In: AGU Fall Meeting Abstracts. Washington: American Geophysical Union, 2010. v. 1, p. 1152.

YIN, Robert K. Case study research: design and methods. Thousand Oaks, CA: Sage, 1994.

Lauro Gonzalez is Ph.D in economy and coordenator from the Centro de Estudos em Microfinanças of the Fundação Getulio Vargas (FGV). E-mail: lauro.gonzalez@fgv.br.

Rafael Magnus Barbosa Moser is MSc in international studies and researcher from the Centro de Estudos em Microfinanças of the Fundação Getulio Vargas (FGV). E-mail: rafaelmoser@hotmail.com. 